\title{
[Regular Paper] \\ Separation of Aromatic Hydrocarbons from Cracked Kerosene by Emulsion Liquid Membrane with Batch Stirred Vessel
}

\author{
Hiroaki HABAKI, Masashi HARUNA, and Ryuichi EGASHIRA* \\ Dept. of International Development Engineering, Tokyo Institute of Technology, \\ 2-12-1 Ookayama, Meguroku, Tokyo 152-8550, JAPAN
}

(Received December 7, 2012)

\begin{abstract}
Cracked kerosene, aqueous solution of polyoxyethylene sorbitan monooleate (Tween80), and hexane were used as the feed oil, membrane solution, and solvent, respectively. A baffled stirred vessel was used as the permeator. The aromatic components could selectively permeate through the emulsion liquid membrane and the yields of aromatic components were much larger than those of alkane components. The mass transfer rates of aromatic components were less affected by membrane breakage, and the permeation of aromatic components through the emulsion liquid membrane was controlling relative to the overall mass transfer. The overall volumetric permeation coefficients of total aromatic components were ten-fold more than those of total alkane components. The overall volumetric permeation coefficients were affected by the stirring velocity and surfactant mass fraction in the membrane phase. The stirring velocity was important for the dispersion of the emulsion phase in the extract phase and the specific surface area should increase with the stirring velocity. The mass fraction of surfactant in the membrane phase should be appropriately adjusted to achieve larger overall permeation coefficient. The separation selectivity of total aromatic components relative to total alkane components reached more than 10 , similar to the previous results of batch liquid-liquid extraction measurements with sulfolane solvent.
\end{abstract}

\section{Keywords}

Aromatic separation, Cracked kerosene, Emulsion liquid membrane, Membrane instability

\section{Introduction}

The demand trend for fossil fuel oil products has recently changed in developed countries. According to the report of International Energy Statistics by the U.S. Energy Information Administration ${ }^{1)}$, the consumption of fossil fuel oil products, especially gasoline consumption, has decreased since 2006 or 2007 in developed countries. Fuel-efficient automobiles, such as hybrid, electric, and other efficient vehicles, have been developed for sale in these countries. The recent hikes in the price of crude oil were coincidentally caused by unstable political situations in Middle East countries, but the reduction of demand for motor gasoline was accelerated more than expected. Consequently, operations at cracking plants, including FCC, should be modified for reduction of motor gasoline production, and other byproducts of cracked oils would be obtained. The markets for motor gasoline are very large in developed countries, so that the quantities of other generated byproducts would also be considerable. Therefore, applications for the surplus products should be explored.

\footnotetext{
* To whom correspondence should be addressed.

* E-mail: regashir@ide.titech.ac.jp
}

As one possibility, aromatic components could be recovered from the cracked oil products and the treated cracked oil products would be utilized as fuel oils for uses other than motor gasoline ${ }^{2)}$. Cracked oil products generally contain high levels of aromatic components. The recovered aromatic components can be utilized as feedstocks for the petrochemical industry. The treated cracked oil products could be used for kerosene and diesel oil, which are required to contain lower levels of aromatic components for effective combustion. Therefore, techniques for recovery of aromatics from the cracked oil products must be developed.

Some processes have been commercialized to recover aromatic components from hydrocarbon mixtures, of which the Sulfolane process is one of the most common $^{3)}$. Reformate gasoline is used as the aromatic source and sulfolane is used as the solvent. In our previous study ${ }^{2}$, cracked kerosene was employed as one of the cracked oil products and the batch liquid-liquid extraction was measured with two sulfolane and methanol solvents. The distribution coefficients of the aromatic components were relatively high with these solvents, so the aromatic components could be selectively recovered. The emulsion liquid membrane technique is a possible alternative method to the conventional extrac- 
Table 1 Experimental Conditions of Emulsion Liquid Membrane Permeation

\begin{tabular}{lll}
\hline $\begin{array}{l}\text { Feed } \\
\text { Membrane }\end{array}$ & $\begin{array}{l}\text { Cracked kerosene } \\
\text { Aqueous solution of surfactant of } \\
\text { polyoxyethylene (20) sorbitan monooleate (Tween80) } \\
\text { mass fraction of surfactant in membrane, } C_{\mathrm{S}}=0.005-0.2\end{array}$ \\
Hexane & & \\
Solvent & {$\left[\mathrm{h}^{-1}\right]$} & $1.1 \times 10^{6}$ \\
Stirring velocity in emulsification & {$\left[\mathrm{h}^{-1}\right]$} & $1.8 \times 10^{4}-3.6 \times 10^{4}$ \\
Stirring velocity during permeation, $N_{\mathrm{P}}$ & {$\left[\mathrm{m}^{3}\right]$} & $4.0 \times 10^{-4}$ \\
Total volume of liquid & {$[-]$} & 0.5 \\
Initial volume fraction of feed oil in O/W emulsion & {$[-]$} & 0.25 \\
Initial volume fraction of O/W emulsion in total liquid & {$[\mathrm{h}]$} & $0-0.25$ \\
Operation time, $t$ & {$[\mathrm{~K}]$} & $298 \pm 5$ \\
Operation temperature & & \\
\hline
\end{tabular}

tion method for the recovery of aromatic compounds from hydrocarbon mixtures. This method has been studied since $1968^{4)}$ and much research has been reported on the separation of hydrocarbons, including aromatic recovery by an emulsion liquid membrane, in which naphtha ${ }^{5), 6)}$, reformate gasoline ${ }^{7)}$, kerosene ${ }^{8)}$, or light cyclic oil ${ }^{9)}$ were used as the feedstocks. However, the separation of cracked kerosene with this technique has not been studied yet.

The present study reports application of the emulsion liquid membrane to the separation of aromatic components from cracked kerosene. A stirred vessel was used as a permeator and batch emulsion liquid membrane permeation was conducted with various surfactant concentrations in the membrane phase and stirring velocities. The permeation rates of aromatic and alkane components were measured, considering the effects of the membrane instability due to membrane breakage. The separation of aromatic components from the cracked kerosene was evaluated in terms of the overall permeation coefficients and separation selectivities of the aromatic components relative to the alkane components.

\section{Experimental}

The experimental conditions for emulsion liquid membrane separation are listed in Table 1 . The permeator consisted of a stirred vessel made of cylindrical Pyrex glass with a six-flat-blade turbine type impeller and four baffles, as shown in Fig. 1. Cracked kerosene, provided from one of the refineries in Japan, was used as the feed phase. Polyoxyethylene (20) sorbitan monooleate (Tween80) was selected as the surfactant and an aqueous solution of Tween 80 was used as the membrane phase for the preparation of the O/W emulsion. Hexane was selected as the solvent phase among the hydrocarbons with boiling points lower than that of cracked kerosene. The mass fraction of Tween 80 in the membrane phase and stirring velocity during permeation were changed as experimental parameters. The feed cracked kerosene and aqueous membrane solution

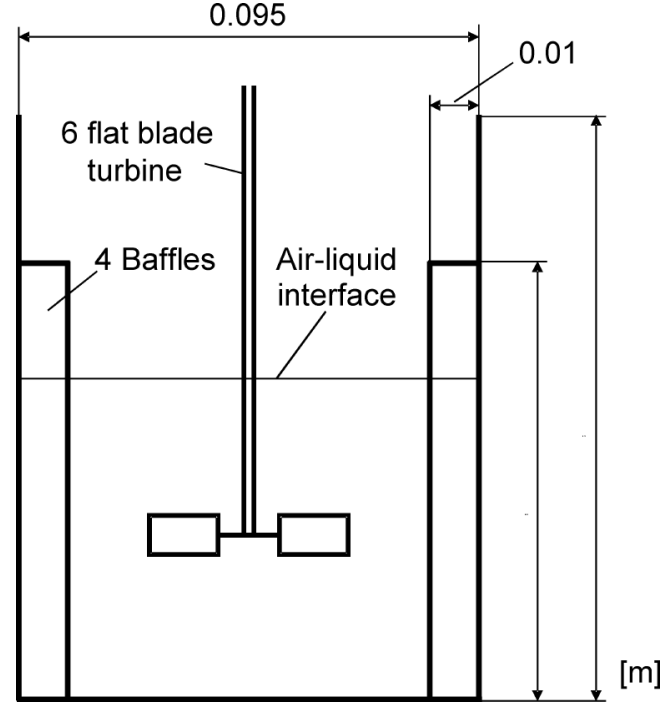

Fig. 1 Schematic Diagram of Stirred Vessel for Emulsion Liquid Membrane Permeation

were stirred by a commercial high-speed homogenizer (SMT Multi Disperser, SMT Corp.) to prepare the feed $\mathrm{O} / \mathrm{W}$ emulsion. Then the prepared emulsion was brought into contact with the solvent in the stirred vessel. The time of starting the agitation was defined as $t=0$ of the permeation and the agitation was maintained for a specified operating time. During the permeation, the $\mathrm{O} / \mathrm{W} / \mathrm{O}$ dispersion had a free surface. After permeation for the specified period, the agitation was stopped, and the emulsion and extract phases were separated with a separating funnel. The extract phases were analyzed with a gas chromatograph (GC-2010, Shimadzu Corp.) to determine the compositions in the extract phases. These operations were repeated for several different periods of permeation to obtain the time courses of the compositions in the extract phases, etc. The compositions of the raffinate phases were determined by the mass balance relationships with the compositions of the extract phases and so on. 
Table 2 Mass Fractions of Identified Components in Cracked Kerosene

\begin{tabular}{lcc}
\hline \multicolumn{1}{c}{ Components } & Mass fraction $[-]$ & Mass fraction $^{\text {a) }}[-]$ \\
\hline Toluene & 0.0025 & 0.0026 \\
Ethylbenzene & 0.0060 & 0.0067 \\
$m, p$-Xylene & 0.0236 & 0.0233 \\
$o$-Xylene & 0.0155 & 0.0175 \\
Propylbenzene & 0.0038 & 0.0041 \\
1,3,5-Trimethylbenzene & 0.0147 & 0.0142 \\
1,2,4-Trimethylbenzene & 0.0131 & 0.0131 \\
Tetraline & 0.0094 & 0.0094 \\
Naphthalene & 0.0038 & 0.0044 \\
Hexylbenzene & 0.0100 & 0.0091 \\
2-Methylnaphthalene & 0.0082 & 0.0080 \\
Heptane & 0.0014 & 0.0017 \\
Octane & 0.0171 & 0.0168 \\
Nonane & 0.0738 & 0.0671 \\
Decane & 0.0362 & 0.0337 \\
Undecane & 0.0342 & 0.0319 \\
Dodecane & 0.0331 & 0.0331 \\
Tridecane & 0.0372 & 0.0357 \\
Tetradecane & 0.0272 & 0.0254 \\
Pentadecane & 0.0203 & 0.0194 \\
Hexadecane & 0.0085 & 0.0086 \\
Heptadecane & 0.0020 & 0.0026 \\
\hline Total aromatics & 0.111 & 0.113 \\
Total alkanes & 0.291 & 0.274 \\
\hline a) Cited & &
\end{tabular}

a) Cited from previous study ${ }^{2)}$.

\section{Results and Discussion}

Table 2 shows the components and compositions identified in the cracked kerosene. A total of 23 components including 12 aromatics and 11 alkanes could be identified with GC, and the total mass fractions of identified aromatic and alkane components were 0.11 and 0.29 , respectively. The composition in the cracked kerosene was almost the same as that measured in the previous study ${ }^{2}$. The single ring aromatic components were the most common among the identified aromatic components. The carbon numbers of the identified alkane components varied from 7 to 18 . The peaks of meta- and para-xylenes in the GC chromatogram overlapped and these components were treated as a single component in the following discussion.

Stable emulsion could be prepared with cracked kerosene and the aqueous solution of Tween80. In all permeation runs, stable operation could achieved with the prepared emulsion and extract phase of hexane. The prepared emulsion was stable during permeation under any conditions and the volume change of the emulsion was small. The effects of instabilities on the emulsion will be discussed below. Fast phase separation between the emulsion and extract phase was observed and settling was completed within $10 \mathrm{sec}$. According to visual observations, the obtained extract phase was transparent and the extract phase might not contain any tiny droplets of the emulsion.
The material balance of component $i$ for the batch emulsion liquid membrane permeation can be expressed as,

$$
R_{0} \cdot x_{i, 0}+E_{0} \cdot y_{i, 0}=R \cdot x_{i}+E \cdot y_{i}
$$

where $R, E, x_{i}$ and $y_{i}$ stand for the masses of the raffinate and extract phases, and the mass fractions of component $i$ in the raffinate and extract phases, respectively. The subscript 0 means the initial condition. The yield of component $i$ was defined as,

$$
Y_{i}=\frac{E \cdot y_{i}}{R_{0} \cdot x_{i, 0}}
$$

The overall permeation coefficient, $P_{i}$, was defined as,

$$
\frac{\mathrm{d}\left(E \cdot y_{i}\right)}{\mathrm{d} t}=P_{i} \cdot a \cdot\left(x_{i}-y_{i}\right) \cdot V_{\mathrm{T}}+W_{\mathrm{b}} \cdot x_{i}-W_{\mathrm{ent}} \cdot y_{i}
$$

here $a, V_{\mathrm{T}}, W_{\mathrm{b}}$ and $W_{\text {ent }}$ stand for the specific surface area, total liquid volume in the vessel, membrane breakage rate, and mechanical entrainment rate, respectively. The feed cracked kerosene contained nonane with the highest mass fraction among the identified alkane components, as shown in Table 2 . The solubility of nonane in the membrane phase was so small that the permeation of this component was assumed to be negligible. Then, $W_{\mathrm{b}}$ was determined by the following Eq. (4):

$$
W_{\mathrm{b}}=\frac{1}{x_{\mathrm{C} 9}} \cdot \frac{\mathrm{d}\left(E \cdot y_{\mathrm{C} 9}\right)}{\mathrm{d} t}
$$

The entrainment rate, $W_{\mathrm{ent}}$, was not measured and $P_{i}$ • $a$ was estimated assuming that $W_{\text {ent }}=0$ using Eq. (3). The separation selectivity of total aromatic components relative to total alkane components, $\beta_{\mathrm{TAr}, \mathrm{TAl}}$, was defined as,

$$
\beta_{\mathrm{TAr}, \mathrm{TAl}}=\frac{\frac{\mathrm{d}\left(E \cdot y_{\mathrm{TAr}}\right)}{\mathrm{d} t} /\left(x_{\mathrm{TAr}}-y_{\mathrm{TAr}}\right)}{\frac{\mathrm{d}\left(E \cdot y_{\mathrm{TAl}}\right)}{\mathrm{d} t} /\left(x_{\mathrm{TAl}}-y_{\mathrm{TAl}}\right)}
$$

Then, this equation can be rewritten as,

$$
\beta_{\mathrm{TAr}, \mathrm{TAl}}=\frac{P_{\mathrm{TAr}}}{P_{\mathrm{TAl}}}
$$

Separation by the liquid membrane is controlled by the difference in the permeation rates of the objective components. The separation selectivity of the liquid membrane was defined by the ratio of the overall permeation coefficients of the objective components, as shown in Eq. (5'). The scale of the stagewise contactor and operating conditions of the emulsion liquid membrane can be approximately determined according to these rate parameters. On the other hand, the solvent extraction is based on the equilibrium separation. The separation selectivity could be defined by the ratio 
of distribution coefficients of the objective components, as shown in the previous study ${ }^{2}$, to show the separation efficiency at the equilibrium stage.

The components for evaluation of the emulsion liquid membrane permeation were chosen from the identified components with mass fractions larger than 0.01 in the feed cracked kerosene. The $y_{i}$ of the other components were too small to ensure adequate reproducibility. Tetradecane and pentadecane were also removed from the components for the evaluation because the $y_{i}$ of these two components were too small to determine their peaks in the chromatograms. Therefore, the separation of cracked kerosene will be discussed based the aromatic components including xylenes, propylbenzene, trimethylbenzenes, and hexylbenzene, and the alkane components with carbon numbers from 8 to 13 .

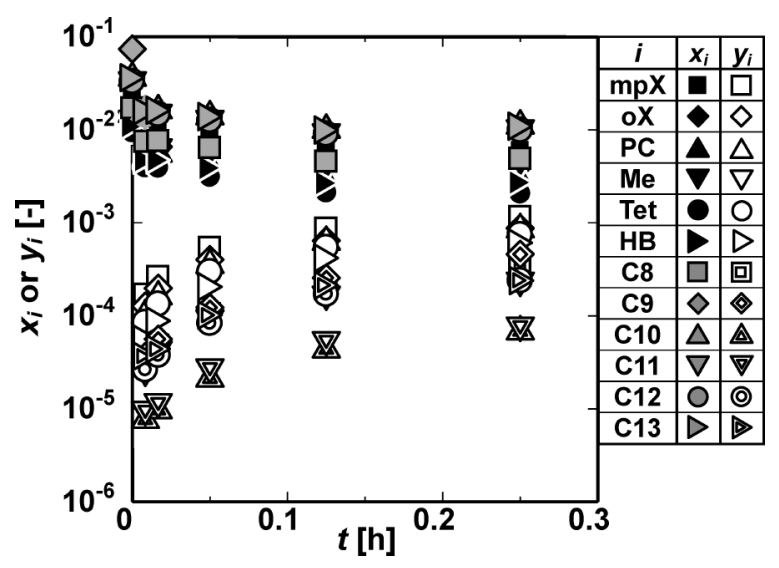

$C_{\mathrm{S}}: 0.03, N_{\mathrm{P}}: 1.8 \times 10^{4} \mathrm{~h}^{-1}$.

Fig. 2 Example of Time Courses of $y_{i}$ and $x_{i}$
Figure 2 shows the examples of the time courses of the mass fractions in the raffinate and extract phases, $x_{i}$ and $y_{i}$, respectively. Figure 3 show the effects of the stirring velocity during the permeation, $N_{\mathrm{P}}$, and the mass fraction of surfactant in the membrane phase, $C_{\mathrm{S}}$, on the mass fractions of the total aromatics and alkanes, $x_{\mathrm{TAr}}$, $y_{\mathrm{TAr}}, x_{\mathrm{TAl}}$ and $y_{\mathrm{TAl}}$, defined as the summations of the respective mass fractions of aromatic and alkane components. In all cases, $x_{i}$ decreased and $y_{i}$ increased with contact time, respectively. The $y_{i}$ of aromatic components were larger than the $y_{i}$ of alkane components, although the $x_{i}$ of aromatic components were smaller than the $x_{i}$ of alkane components. The aromatic components selectively permeated though the membrane phase. Among the aromatic components, the $y_{i}$ of xylenes were larger than those of other aromatic components. $C_{\mathrm{S}}$ affected $y_{i}$ to attain maximum value around $C_{\mathrm{S}}=0.05$. The stirring rate, $N_{\mathrm{P}}$, was influential and $y_{i}$ increased as $N_{\mathrm{P}}$, possibly simply because the particle sizes of the dispersed emulsion globules became smaller as $N_{\mathrm{P}}$ increased, and the specific contact area increased. However, the particle size distribution of emulsion globules during permeation was not measured in this study.

Figure 4 shows the effects of $C_{\mathrm{S}}$ and $N_{\mathrm{P}}$ on the yields of total aromatic and alkane components, $Y_{\mathrm{TAr}}$ and $Y_{\mathrm{TAl}}$, respectively. In any case, $Y_{i}$ s of aromatic compounds were larger than those of alkane compounds, namely, the aromatic components could be selectively recovered by the emulsion liquid membrane. As in the explanation of Fig. 3, $Y_{i}$ increased with $N_{\mathrm{P}}$, and reached maximum value around $C_{\mathrm{S}}=0.05$. For reference, the total aromatic component yields in the previous study are shown as the solid lines in this fig-
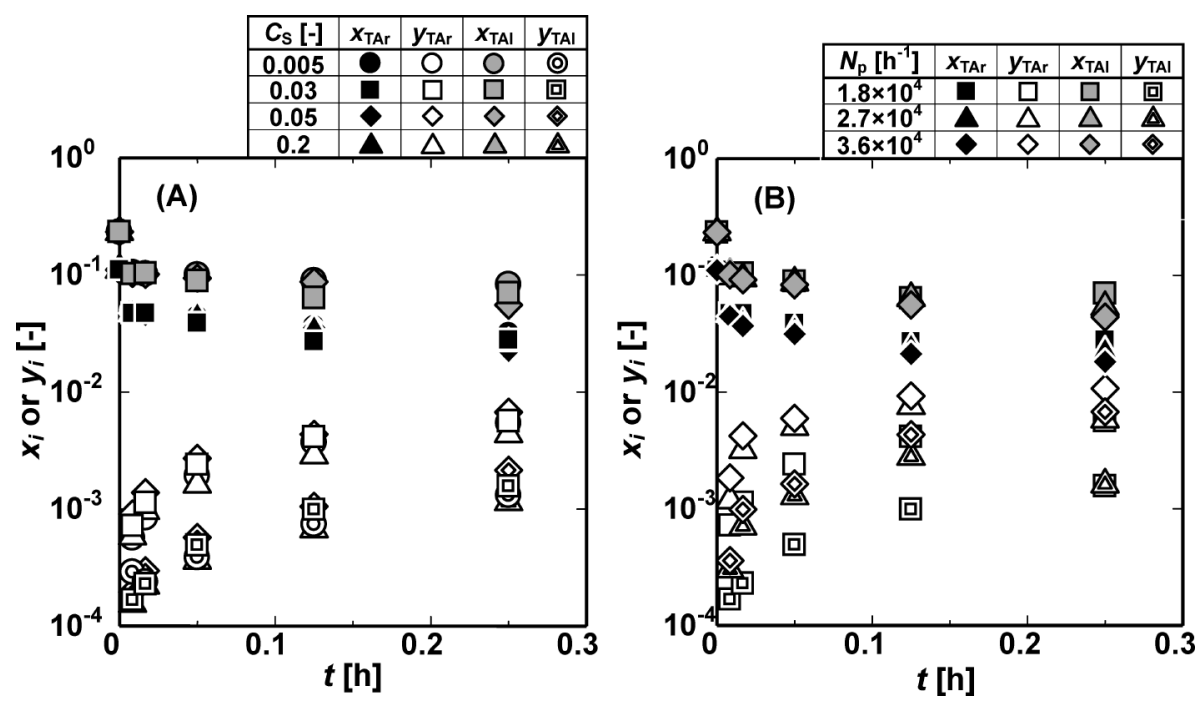

(A) $N_{\mathrm{P}}: 1.8 \times 10^{4} \mathrm{~h}^{-1}$, (B) $C_{\mathrm{S}}: 0.03$.

Fig. 3 Effects of $C_{\mathrm{S}}$ and $N_{\mathrm{P}}$ on Mass Fractions of Total Aromatic and Alkane Components in Raffinate and Extract Phases 

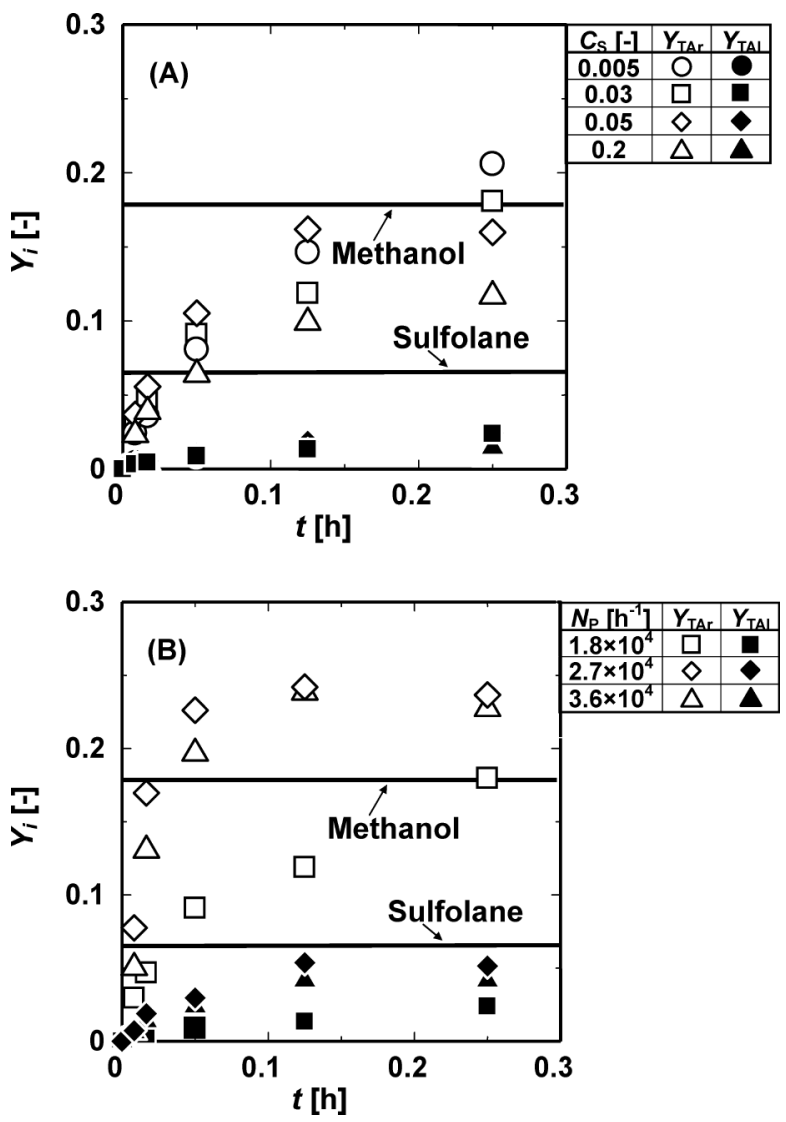

(A) $N_{\mathrm{P}}: 1.8 \times 10^{4} \mathrm{~h}^{-1}$, (B) $C_{\mathrm{S}}: 0.03$. Solid lines: cited from previous study $^{2)}$.

Fig. 4 Effects of $C_{\mathrm{S}}$ and $N_{\mathrm{P}}$ on Yields of Total Aromatic and Alkane Components

ure. The emulsion liquid membrane could attain comparable yields with batch liquid-liquid extraction with methanol solvent.

Figure 5 shows the contributions of the membrane breakage rates, $W_{\mathrm{b}}$, to the net mass transfer rates of total aromatic and alkane components, $\frac{\mathrm{d}\left(E \cdot y_{i}\right)}{\mathrm{d} t}$. The effects of $W_{\mathrm{b}}$ on the net mass transfer rates of total aromatic components were so small that permeation through the membrane phase was controlling for the mass transfer of aromatic components. The mass transfer rates of total alkane components were comparable to $W_{\mathrm{b}}$, and the effects of membrane breakage on the mass transfer of total alkane components were large.

Figure 6 show the effects of $N_{\mathrm{p}}$ and $C_{\mathrm{S}}$ on the overall volumetric permeation coefficients, $P_{i} \cdot a . \quad P_{i} \cdot a$, of total aromatic compounds were approximately ten-fold larger than those of total alkane compounds. In any case, $P_{i} \cdot a$ decreased with the contact time. The decrease of $P_{i} \cdot a$ was faster for aromatic components than for alkane components. If the solubilities of the objective components into the membrane solution are absolutely small, the concentration profiles of the objective
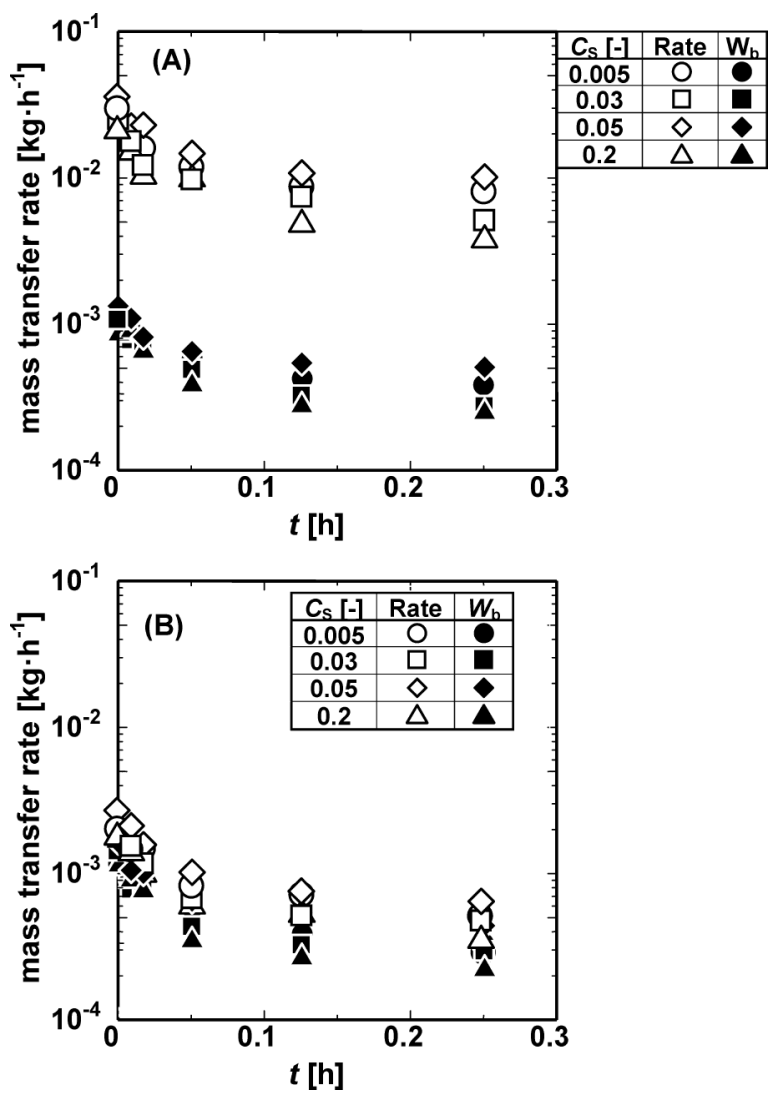

$N_{\mathrm{P}}: 1.8 \times 10^{4} \mathrm{~h}^{-1}$.

Fig. 5 Contribution of $W_{\mathrm{b}}$, Black Keys, to Overall Mass Transfer Rates of Total Aromatic (A) and Alkane Components (B), White Keys

components would inevitably develop in the emulsion globules as the permeation proceeded ${ }^{10)}$. Substantially the components could permeate only from the feed phase drops in the vicinity of the surface of the emulsion globules. The development of the concentration profiles reduced the overall permeation coefficient defined as Eq. (3) and reduction of this measurement could be observed. The components with larger solubilities, such as aromatic components, should permeate to the extract phase first, then the less permeable components, such as alkane components, should be concentrated in the feed phase drops. Accordingly, the decrease in $P_{i} \cdot a$ with time was different for the aromatic and alkane components. $\quad P_{i} \cdot a$ also increased with $N_{\mathrm{P}}$ since the specific surface area might increase with $N_{\mathrm{P}}$. $C_{\text {S }}$ also affected $P_{i} \cdot a$, showing the maximum value of $P_{i} \cdot a$ around $C_{\mathrm{S}}=0.05$, which might be caused mainly by variations in the specific surface area. Surfactant generally decreases the interfacial tension between the organic and aqueous phases. The interfacial tension decreased with higher mass fraction of surfactant. The diameters of the emulsion globules in the extract phase should change with $C_{\mathrm{S}}$, as shown previously ${ }^{11}$. The 

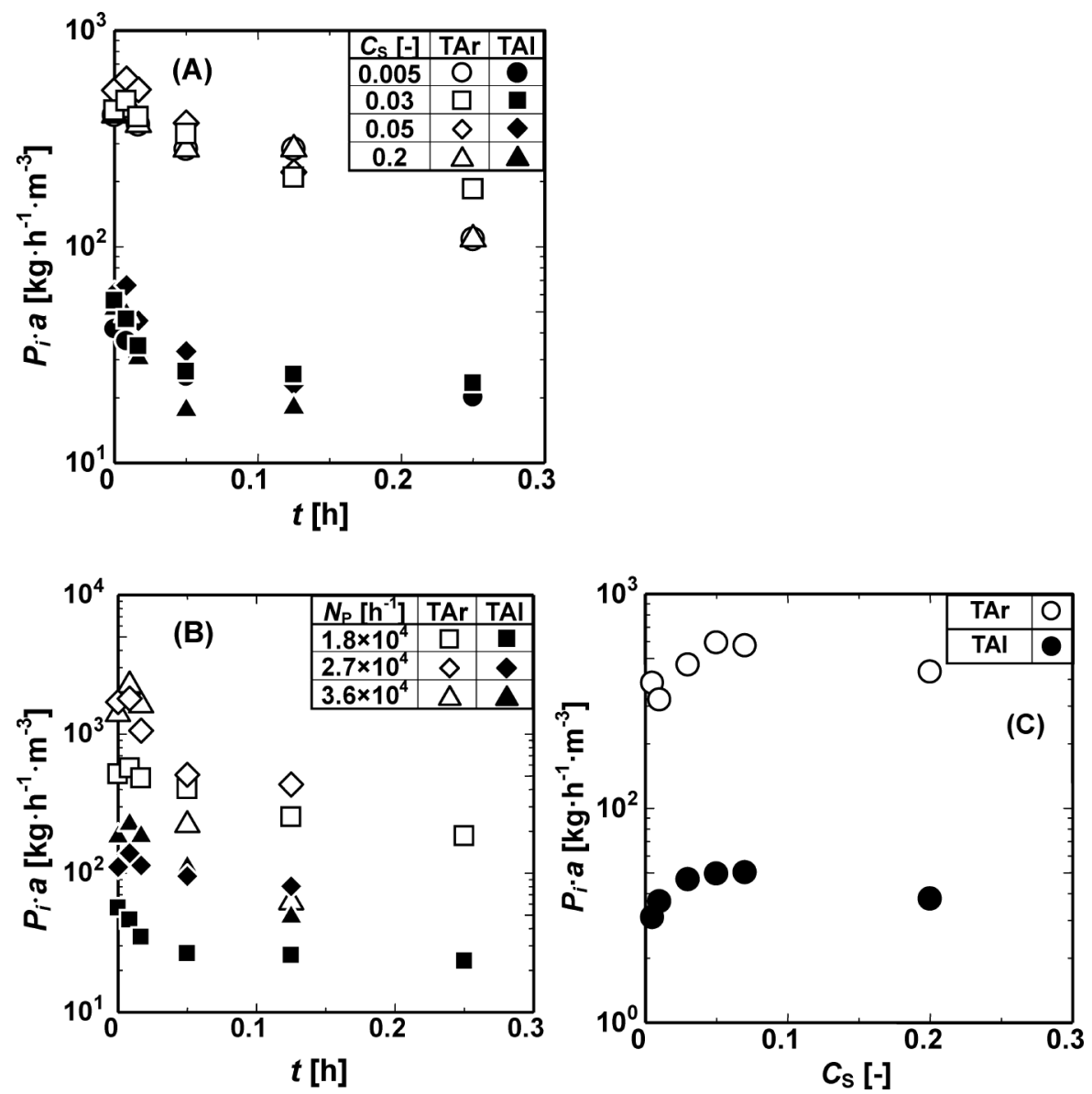

(A) $N_{\mathrm{P}}: 1.8 \times 10^{4} \mathrm{~h}^{-1},(\mathrm{~B}) C_{\mathrm{S}}: 0.03,(\mathrm{C}) N_{\mathrm{P}}: 1.8 \times 10^{4} \mathrm{~h}^{-1}, t: 0.0083 \mathrm{~h}(30 \mathrm{sec})$.

Fig. 6 Effects of $N_{\mathrm{P}}$ and $C_{\mathrm{S}}$ on Overall Volumetric Permeation Coefficients of Total Aromatic and Alkane Components

diameters of emulsion globules should decrease with $C_{\mathrm{S}}$ in the lower range of $C_{S}$. In the higher $C_{S}$ range, the diameter should increase with $C_{\mathrm{S}}$. These effects might be observed in this measurement and, consequently, $P_{i}$. $a$ increased with $C \mathrm{~s}$ in the range of $C_{\mathrm{S}}<0.05$, reached the maximum value around $C_{\mathrm{S}}=0.05$, and decreased in the range of $C_{S}>0.05$, as shown in Fig. $6(\mathbf{C})$.

Figure 7 shows the time courses of $\beta_{\text {TAr,TAl. }}$ The obtained $\beta_{\text {TAr,TAl }}$ was adequate at more than 10 and the total aromatic components could selectively permeate through the emulsion liquid membrane. $\beta_{\mathrm{TAr}, \mathrm{TAl}}$ gradually decreased with time, which was attributed to the finding that $P_{i} \cdot a$ of the aromatic components declined more quickly with contact time than those of alkane compounds. $\quad C_{\mathrm{S}}$ and $N_{\mathrm{P}}$ had little effect on $\beta_{\mathrm{TAr}, \mathrm{TAl}}$ since their effects, as mentioned above, might equally affect the $P_{i} \cdot a$ of both aromatic and alkane components. In our previous study ${ }^{2}$, the batch liquid-liquid extraction was measured with methanol and sulfolane solvents, and the separation selectivities are shown as solid lines in Fig. 7. The separation selectivity in this study was comparable to that measured in the previous study with sulfolane solvent. Therefore, both methods should be studied further as possible methods for aromatic recovery from cracked oils.

In comparison with the previous findings of batch equilibrium extraction ${ }^{2}$, the separation selectivity of the aromatic components by the emulsion liquid membrane was approximately equivalent to that by extraction with sulfolane, and the recovery of aromatic components was approximately twice that by extraction with sulfolane, and similar to that with methanol. In the case of the emulsion liquid membrane, the extraction phase can be selected among hydrocarbons, in which the objective components can dissolve at higher level or with which the feed oil forms the homogeneous phase. In this study, hexane was used as the extraction phase and any component in the cracked kerosene could freely dissolve in the extraction phase. In the case of solvent extraction, the solubilities of the objective components should be limited because the solvent is required to form two phases with the feed oil. In practical use, the operation should be carried out using a multi-stage contactor. Although the separation selectivity can be 

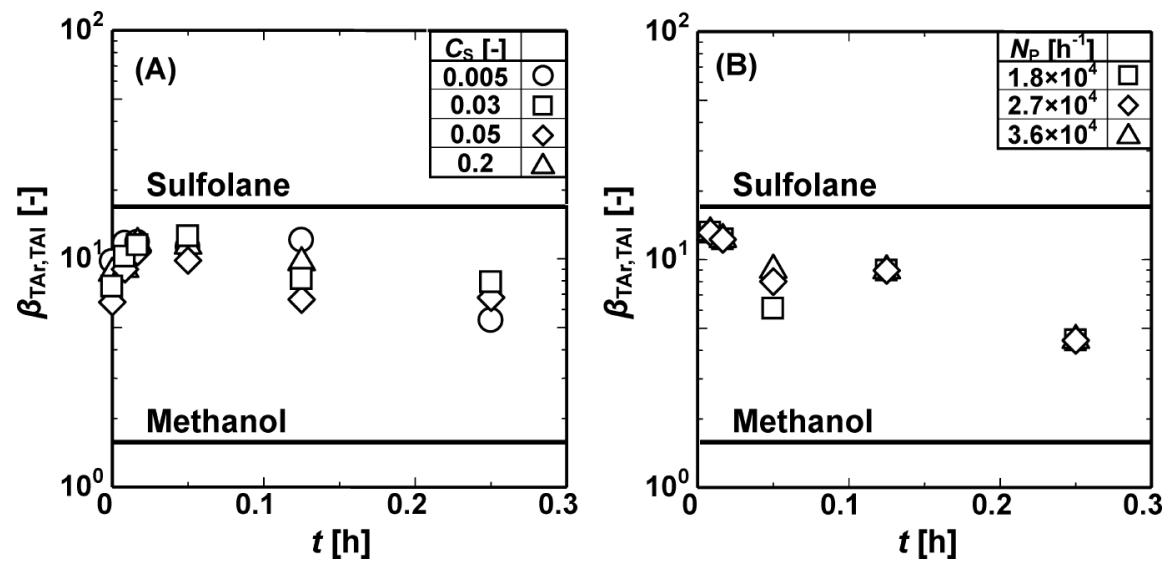

(A) $N_{\mathrm{P}}: 1.8 \times 10^{4} \mathrm{~h}^{-1}$, (B) $C_{\mathrm{S}}: 0.03$. Solid lines: cited from previous study ${ }^{2}$.

Fig. 7 Effects of $C_{\mathrm{S}}$ and $N_{\mathrm{P}}$ on Separation Selectivity of Total Aromatic Components Relative to Total Alkane Components

enhanced by staging and reflux for both methods, greater flow rate of the solvent phase will be required in the case of the solvent extraction to attain the specifications of the yields due to limitations of the solubility. The emulsion liquid membrane can be expected to attain the specifications with lower flow rate of the solvent phase. This difference should have larger effects on the heat required for the downstream operations, such as solvent recovery and so on, whereas operation with higher flow rate of solvent will involve greater heat requirements. Moreover, in this study, hexane was selected among the hydrocarbons with boiling points lower than that of the cracked kerosene. The liquid membrane method can offer a wider range of choice in solvent than the extraction method. Therefore, the emulsion liquid membrane might be a more attractive method for this separation process. However, the emulsion liquid membrane will make the separation process more complicated than ordinary solvent extraction. Additional operations such as emulsification and demulsification are necessary, and treatment for the used surfactant will be required. Further studies are still essential by comparing liquid membrane separation with solvent extraction.

\section{Conclusions}

The aromatic components in cracked kerosene selectively permeated though the liquid membrane even though the mass fractions of total alkane components in the raffinate phase were always higher than those of aromatic components. The mass transfer rates increased with the stirring velocity due to increased specific surface area. The mass fraction of surfactant in the membrane phase affected the overall volumetric permeation coefficient. In the lower range of the surfactant mass fraction, the interfacial tension between the membrane and raffinate/extract phases was important to make the specific surface area increase with the surfactant mass fraction. In the higher range of the surfactant mass fraction, the emulsion globules should be increased with the surfactant mass fraction. Therefore, the mass fraction of surfactant should be appropriately adjusted for effective permeation. The separation selectivity of total aromatic components relative to total alkane components was high enough to reach more than 10 . The value was comparable with the previous results of batch liquid-liquid equilibrium extraction, in which sulfolane was used as extraction solvent. Both methods should be studied further as techniques of aromatic recovery from cracked kerosene.

\section{Nomenclatures}

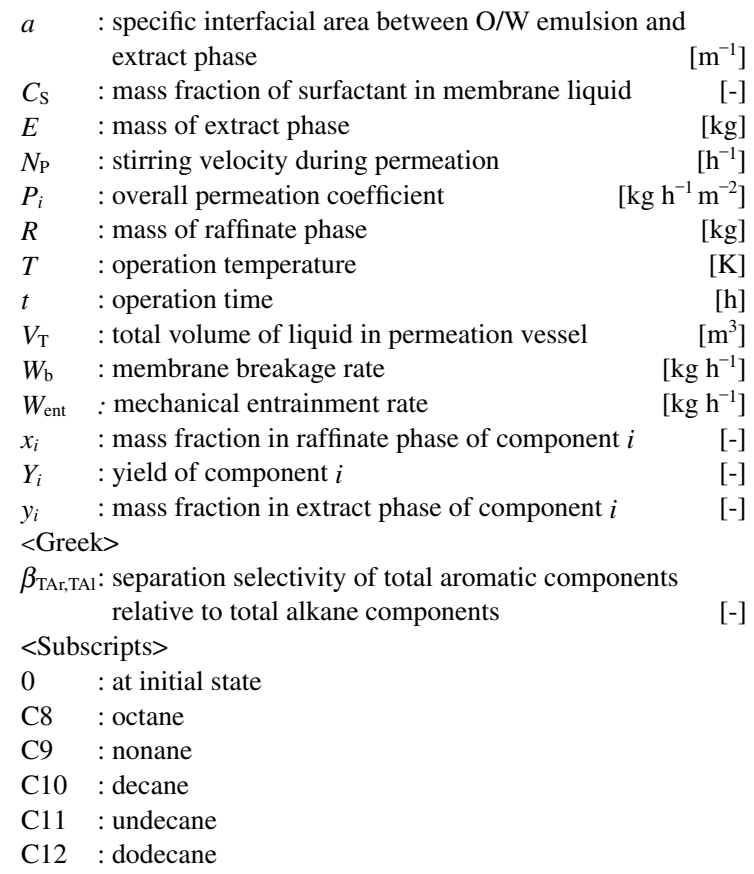




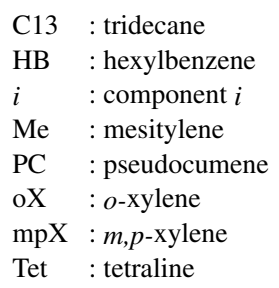

\section{References}

1) "International Energy Statistics," International Energy Statistics by U.S. Energy Information Administration, http://205.254.135.7/countries/.

2) Habaki, H., Miyazaki, M., Egashira, R., J. Jpn. Petrol. Inst., 55, (4), 241 (2012).
3) Deal Jr., G. H., Evans, H. D., Oliver, E. D., Papadopoulos, M. N., Petroleum Refiner, 38, (9), 185 (1959).

4) Li, N. N., US Pat. 3410794, November (1968).

5) Kato, S., Kawasaki, J., Sekiyu Gakkaishi (J. Jpn. Petrol. Inst.), 29, (5), 404 (1986).

6) Kato, S., Kawasaki, J., Sekiyu Gakkaishi (J. Jpn. Petrol. Inst.), 30, (4), 243 (1987).

7) Egashira, R., Habaki, H., Kawasaki, J., Sekiyu Gakkaishi (J. Jpn. Petrol. Inst.), 40, (2), 107 (1997).

8) Anshu, S., Goswami, A. N., Rawat, B. S., Krinshna, R., J. Membr. Sci., 32, (1), 19 (1987).

9) Kim, S. J., Egashira, R., Kawasaki, J., Sekiyu Gakkaishi (J. Jpn. Petrol. Inst.), 38, (2), 114 (1995).

10) Egashira, R., Tanno, H., Kato, S., Kawasaki, J., J. Chem. Eng. Jpn., 28, (1), 38 (1995)

11) Yamamoto, T., Tanaka, M., J. Chem. Eng. Jpn., 36, (8), 963 (2003).

要旨

\title{
回分式擋拌槽を用いた乳化液膜による分解灯油からの芳香族分離
}

\author{
鉵 広顕，春名 将資，江頭 竜一 \\ 東京工業大学大学院理工学研究科国際開発工学専攻，152-8552 東京都目黒区大岡山2-12-1
}

原料として分解灯油を，膜液としてポリオキシエチレンソル ビタンモノオレアート（Tween80）水溶液を, 溶媒としてへキ サンを使用した。邪魔板付き擋挷槽を透過装置として使用し た。芳香族成分は乳化液膜を選択的に透過し, その収率は直鎖 炭化水素に比較して非常に大きかった。芳香族成分の物質移動 に関して膜破壊の影響は小さく，物質移動に対して乳化液膜透 過が支配的であった。全芳香族の総括透過容量係数は直鎖炭化 水素に対して 10 倍以上大きかった。摚拌速度および膜液中の
界面活性剤濃度は総括透過容量係数に影響した。擋拌速度は抽 出相中におけるエマルションの分散に影響し, 擋拌速度の増加 とともに比表面積が増加した。膜液中における界面活性剤の質 量分率を適切に調整することにより総括透過係数を増大させる ことが可能であった。全直鎖炭化水素に対する全芳香族の分離 の選択率は 10 以上となり, 既往の研究結果であるスルホラン 溶媒を用いた回分液液平衡抽出と同等であった。 